UDC 614.31: 613.26

DOI: $10.21668 /$ health.risk/2019.2.04.eng

\title{
HYGIENIC ASSESSMENT OF POPULATION HEALTH RISKS CAUSED BY COMBINED ORAL INTRODUCTION OF HEAVY METALS
}

\author{
V.M. Boev, E.A. Kryazheva, D.N. Begun, E.L. Borshchuk, D.A. Kryazhev \\ The Orenburg State Medical University, 6 Sovetskaya Str., Orenburg, 460000, Russian Federation
}

There is a pressing issue related to combined oral introduction of heavy metals into a human body with drinking water and food products. It is caused by food products contamination, very high probability that metals migrate into water and plants from soils, ambient air, etc. The research goal was to hygienically assess combined oral introduction of heavy metals with drinking water and food products with subsequent population health risks assessment. The authors analyzed long-term data on structure and volumes of food products consumption and assessed population exposure under combined oral introduction of heavy metals (mercury, cadmium, arsenic, and lead) contained in drinking water and food products. Data were obtained from a regional information social-hygienic monitoring database and a regional office of the Federal Statistics Service. Both regional products and products delivered from other regions (or countries) were analyzed. It was detected that population in the region consumed food products per 1 person a year in a quantity which was by $93 \mathrm{~kg}$ higher than on average in the country. Calculated concentrations of the examined substances in food products and drinking water corresponded to hygienic standards. Dairy products had the first rank place as regards a contribution made into the overall exposure to lead, cadmium, and arsenic. The second and the third place belonged to vegetables and melons and grocery respectively. The first rank place as per a contribution made into the overall exposure to mercury belonged to vegetables and melons; the second place, to grocery; the third place, to dairy products. Non-carcinogenic risk assessment revealed that hazard quotients related to heavy metals contents in food products and drinking water were within acceptable risks limits. Total carcinogenic risk (TCR) was unacceptable (1.5E-03.). A number of additional oncologic diseases in the region could reach 557 cases (during 70 years) under the worst scenario.

Key words: food products, drinking water, heavy metals, health risk assessment, non-carcinogenic risk, oncologic diseases, combined effect, oral introduction.

Food products quality has become a population with healthy nutrition up to 2020" pressing issue over the last few years as the (dated October 25, 2010 No. 1873-p) ${ }^{1}$, which Russian Federation is being integrated into the determine priority trends in the state policy world economy, food exports are growing, ag- concerning provision of population with riculture is developing fast, and up-to-date healthy nutrition in accordance with advanced technologies are being implemented into ani- medical requirements. And here it is truly vital mal breeding and plant growing [1,2]. The RF to perform hygienic assessment of contamiGovernment approved on "The Fundamentals nants in food products and determine priority of the RF State Policy concerning provision of contaminants, and to rank food products

(C) Boev V.M., Kryazheva E.A., Begun D.N., Borshchuk E.L., Kryazhev D.A., 2019

Viktor M. Boev - Doctor of Medical Sciences, Professor, Honored scientist of the RF, Honored worker of the higher education in the Russian Federation, Head of the Common and Communal Hygiene Department (e-mail: k com.gig@orgma.ru; tel.: +7 (3532) 50-06-06 (ext. 320); ORCID: http://orcid.org/orcid.org/0000-0002-3684-1149).

Elena A. Kryazheva - a post-graduate student at the Common and Communal Hygiene Department (e-mail: kryazheva89@inbox.ru; tel.: +7(3532) 50-06-06 (ext. 320); ORCID: http://orcid.org/0000-0003-3527-2068).

Dmitrii N. Begun - Candidate of Medical Sciences, Associate Professor at the Public Health and Healthcare Department (e-mail: doctorbegun@yandex.ru; tel.: +7(3532) 50-06-06 (ext. 306); ORCID: https://orcid.org/0000-0002-8920-6675).

Evgenii L. Borshchuk - Doctor of Medical Sciences, Professor, Head of the Public Health and Healthcare Department (e-mail: be@orgma.ru; tel.: +7(3532) 50-06-06 (ext. 306); ORCID: https://orcid.org/0000-0002-3617-5908).

Dmitrii A. Kryazhev - Candidate of Medical Sciences, Associate Professor at the Common and Communal Hygiene Department (e-mail: kryazhev.87@inbox.ru; tel.: +7(3532) 50-06-06 (ext.320); ORCID: http://orcid.org/0000-0003-4592-3848).

${ }^{1}$ The Fundamentals of the RF state Policy concerning provision of population with healthy nutrition up to 2020 / approved by the RF Government Order issued on October 25, 2010 No. 1873-r [web-source] // The RF Government. - URL: http:// government.ru/docs/29017/ (date of visit February 05, 2019). 
groups as per a contribution made by them into overall exposure $^{2}$ [3].

Food products quality and safety is determined, among other things, by absence of alien chemicals (contaminants) in them. Due to heavy metals being widely spread in the environment, it is essential to hygienically assess heavy metals contents, both in food products and drinking water [4-7]. When exposure to contaminants in food products and drinking water is determined, it allows not only to identify probable outcomes for population health but also to indirectly trace migration routes for examined alien chemicals in the environment [8-11]. Previous research that focused on hygienic assessment of heavy metals and microelements in environmental objects substantiates a biochemical province concept and makes it necessary to explore peculiarities and essence of inter-media migration taking into account regional peculiarities [12-15]. In this respect, if we assess a combined introduction of heavy metals with food products and drinking water, it will help us determine population health risks caused by oral introduction of heavy metals and reduce uncertainties [6, 16-19].

Our research goal was to assess population health risks caused by combined oral introduction of heavy metals with food products and drinking water.

Data and methods. Our research involved examining data on food products consumption by population provided by Orenburg regional office of the Russian Federal State Statistics Service; data obtained via research on food products which are subject to long-term social and hygienic monitoring (2008-2013); data taken from the State Reports "On sanitary and epidemiologic welfare of the population in Orenburg region over 2005-2013 $3^{3}$. Overall, we examined more than 3,000 works on various food products, as well as structure and volumes of food products consumption. We performed a hygienic assessment as regards heavy metals contents in food products (cadmium, lead, mercury, and arsenic) and food products compliance with the requirements fixed in CU TR $021 / 2011$ "On food products safety" ${ }^{4}$. Both local food products and those brought into Orenburg region from other places were assessed in the research; we also assessed food products grown by agricultural enterprises and by local population on their private farms.

Drinking water taken from centralized water supply systems in Orenburg was assessed as per 4 heavy metals contents according to SER 2.1.4.1074-01 "Drinking water. Hygienic requirements to quality of water from centralized drinking water supply systems. Quality control. Hygienic requirements to providing safety of hot water supply" ${ }^{\prime 5}$ (with the latest amendments made on April 2, 2018).

Population health risks related to food products and drinking water were assessed in conformity with MG 2.3.7.2519-09 "Exposure determination and assessment of risks caused by effects produced on population by chemicals contaminants in food products" ${ }^{6}$ and "Guidelines on assessment of population health risk under exposure to chemicals which pollute environment" ${ }^{, 7}$. When ranking food products as per their

\footnotetext{
${ }^{2}$ Working Principles for Risk Analysis for Food Safety for Application by Governments. CAC/GL 62-2007. - Rome: World Health Organization, 2007. - 41 p.

${ }^{3}$ On sanitary-epidemiologic welfare of the population in Orenburg region: State Report (over 2005-2013) [web-source] // The Federal Service for Surveillance over Consumer Rights Protection and Human Well-being, Orenburg regional office. URL: http://56.rospotrebnadzor.ru/gosdoklady (date of visit December 05, 2018).

${ }^{4}$ Customs Union Technical Regulations 021/2011. On food products safety [Web-source] // KODEKS: an electronic fund of legal and reference documentation. - URL: http://docs.cntd.ru/document/902320560 (date of visit February 05, 2019).

${ }^{5}$ SER 2.1.4.1074-01. Drinking water. Hygienic requirements to quality of water from centralized drinking water supply systems. Quality control. Hygienic requirements to providing safety of hot water supply (with the latest amendments made on April 2, 2018) [Web-source] // KODEKS: an electronic fund of legal and reference documentation. - URL: http:// docs.cntd.ru/document/901798042 (date of visit: January 23, 2019).

${ }^{6}$ MG 2.3.7.2519-09. Exposure determination and assessment of risks caused by effects produced on population by chemicals contaminants in food products [web-source]. - URL: https://rospotrebnadzor.ru/documents/details.php?ELEMENT_ID $=4799$ (date of visit January 15, 2019).

${ }^{7} \mathrm{G}$ 2.1.10.1920-04. Guidelines on assessment of population health risk under exposure to chemicals which pollute environment [Web-source] // KODEKS: an electronic fund of legal and reference documentation. - URL: http://docs.cntd.ru/document/1200037399 (date of visit January 15, 2019).
} 
contribution into overall exposure, we calculated a fracture as per each examined substance with simultaneous rank determination. To calculate exposure, we took average long-term volumes of food products consumption, median values, and 90-th percentile. Carcinogenic risks were calculated as per 3 examined substances (cadmium, arsenic, and lead). Non-carcinogenic risks were assessed as per 4 examined substances (cadmium, arsenic, lead, and mercury). We processed the data statistically with Statistica R.10, "StatSoft Inc", and MS Office Excel-2010.

Results and discussion. Population exposure to heavy metals directly depends on food products contamination and quantities in which they are consumed. Comparative analysis of specific food products consumption $(\mathrm{kg}$ per capita) revealed that population in Orenburg region tended to consume more food products annually than in the country in general, both overall and as per specific food products groups; thus, overall annual food products consumption per capita was by $93 \mathrm{~kg}$ higher; vegetables and melons consumption, by $45 \mathrm{~kg}$; milk and dairy products, by $60 \mathrm{~kg}$; but at the same time, people living in Orenburg region consumed less sugar and confectionary, fruit, and potatoes (Table 1).

All the examined food products groups complied with the hygienic requirements fixed in the CU TR "On Food products safety" ${ }^{4}$ as per heavy metals contents.

The next stage of our research was calculating median values and 90-th percentile ones in order to determine exposure as calculated average values could be overestimated or underestimated as compared with a median value (Table 2). We should note that calculated median values and 90-th percentile ones don't exceed levels fixed in the CU TR 021/2011 ${ }^{4}$. We didn't detect any heavy metals in food products from "potatoes" group.

We compared all the obtained data with previous research and revealed that food products contamination with heavy metals tended to decrease as regards the examined food products groups. Lead contents went down by 1.4-1.6 times; cadmium, 1.5-2 times; mercury, 2-2.5 times; arsenic, 2.5-3 times [13].

We detected that milk and dairy products occupied the first rank place as per their contribution into overall exposure to lead, cadmium, and arsenic (Table 3). The second and the third rank places as per contributions made into overall exposure to lead, cadmium, and arsenic, belonged to vegetable and melons and grocery products respectively. Vegetables and melons also held the first rank place as per their contribution into overall exposure to mercury; the second place belonged to grocery products; the third place, to milk and dairy products. It is especially interesting to note that lead, arsenic, and cadmium are carcinogenic, and products that make the greatest contribution into overall exposure to them have the same rank places. When assessing the examined food products groups, we detected that it was exactly grocery products, vegetables

Table 1

Annual food products consumption per capita (kg/year)

\begin{tabular}{|l|c|c|}
\hline \multicolumn{1}{|c|}{ Food products group } & Orenburg region & The Russian Federation \\
\hline Grocery & $121.6 \pm 5.7$ & $118.8 \pm 1.9$ \\
\hline Vegetables and melons & $\mathbf{1 5 0} \pm \mathbf{9 . 6}^{*}$ & $105 \pm 1.9$ \\
\hline Potatoes & $\mathbf{9 6 . 6} \pm \mathbf{6 . 3}$ & $109.6 \pm 2.3$ \\
\hline Fruit and berries & $53.0 \pm 2.3$ & $59.6 \pm 1.6$ \\
\hline Meat and meat products & $69.3 \pm 3.1$ & $65 \pm 1.8$ \\
\hline Milk and dairy products & $\mathbf{3 0 7 . 7} \pm \mathbf{8 . 5}$ & $247 \pm 3.4$ \\
\hline Eggs (items) & $\mathbf{3 1 0 . 7} \pm \mathbf{7 . 6}$ & $269 \pm 5.4$ \\
\hline Fish and fish products & $24.2 \pm 1.9$ & $24.2 \pm 1.1$ \\
\hline Sugar and confectionary & $34.3 \pm 2.1$ & $39.2 \pm 1.4$ \\
\hline Vegetable oil and other fats & $18.3 \pm 1.6$ & $13.5 \pm 1.1$ \\
\hline
\end{tabular}

Note: validity of discrepancies between groups ${ }^{*}-p<0.05$. 
Table 2

Contaminants concentrations in food products for exposure calculation ( $\mathrm{mg} \backslash \mathrm{kg}, \mathrm{M} \pm \mathrm{m}$ )

\begin{tabular}{|l|c|c|c|c|c|}
\hline \multicolumn{2}{|c|}{ Food products group } & Lead & Arsenic & Cadmium & Mercury \\
\hline \multirow{2}{*}{ Grocery } & med & $0.01 \pm 0.0012$ & $0.01 \pm 0.0012$ & $0.01 \pm 0.0011$ & $0.005 \pm 0.0001$ \\
\cline { 2 - 6 } & $90 \%$ & $0.01 \pm 0.001$ & $0.01 \pm 0.0011$ & $0.014 \pm \pm 0.0001$ & $0.005 \pm 0.0001$ \\
\hline \multirow{2}{*}{ Vegetables and melons } & med & $0.01 \pm 0.0013$ & $0.01 \pm 0.0019$ & $0.01 \pm \pm 0.0001$ & $0.005 \pm 0.0001$ \\
\cline { 2 - 6 } & $90 \%$ & $0.01 \pm 0.0017$ & $0.01 \pm 0.0018$ & $0.01 \pm \pm 0.0001$ & $0.005 \pm 0.0001$ \\
\hline \multirow{2}{*}{ Fruit and berries } & med & $0.01 \pm 0.0011$ & $0.01 \pm 0.0011$ & $0.01 \pm 0.001$ & $0.005 \pm 0.0001$ \\
\cline { 2 - 6 } & $90 \%$ & $0.01 \pm 0.0012$ & $0.01 \pm 0.0014$ & $0.01 \pm 0.0011$ & $0.005 \pm 0.0001$ \\
\hline \multirow{2}{*}{ Milk and dairy products } & med & 0 & 0 & 0 & 0 \\
\cline { 2 - 6 } & $90 \%$ & $0.01 \pm 0.0013$ & $0.01 \pm 0.0013$ & $0.01 \pm 0.0001$ & $0.005 \pm 0.0001$ \\
\hline \multirow{2}{*}{ Fish and fish products } & $90 \%$ & $0.01 \pm 0.0011$ & $0.01 \pm 0.001$ & $0.01 \pm 0.0001$ & $0.005 \pm 0.0001$ \\
\hline \multirow{2}{*}{ Sugar and confectionary } & med & $0.01 \pm 0.0011$ & $0.024 \pm 0.001$ & 0 & $0.012 \pm 0.001$ \\
\cline { 2 - 6 } & $90 \%$ & $0.07 \pm 0.0018$ & $0.256 \pm 0.01$ & $0.022 \pm 0.0001$ & $0.05 \pm 0.001$ \\
\hline \multirow{2}{*}{ Vegetable oil and other fats } & $90 \%$ & $0.01 \pm 0.0018$ & $0.01 \pm 0.0014$ & $0.01 \pm 0.0001$ & $0.005 \pm 0.0001$ \\
\cline { 2 - 6 } & $90 \%$ & $0.01 \pm 0.0015$ & 0 & 0 & 0 \\
\hline
\end{tabular}

Table 3

Products rankled as per their contribution into overall exposure $(\%$, rank)

\begin{tabular}{|l|c|c|c|c|}
\hline Products & Lead & Arsenic & Cadmium & Mercury \\
\hline Grocery & $17.6(3)$ & $17.2(3)$ & $18.2(3)$ & $27.0(2)$ \\
\hline Vegetables and melons & $21.7(2)$ & $21.2(2)$ & $22.5(2)$ & $33.3(1)$ \\
\hline Fruit and berries & $7.7(4)$ & $7.5(5)$ & $8.0(4)$ & $11.7(5)$ \\
\hline Meat and meat products & 0 & 0 & 0 & 0 \\
\hline Milk and dairy products & $44.5(1)$ & $43.5(1)$ & $46.2(1)$ & $13.6(3)$ \\
\hline Fish and fish products & $3.5(6)$ & $8.2(4)$ & 0 & $12.9(4)$ \\
\hline Sugar and confectionary & $5.0(5)$ & $2.4(6)$ & $5.1(5)$ & $1.5(6)$ \\
\hline
\end{tabular}

and melons, meat, milk and dairy products that were mainly produced or grown locally, in Orenburg region. We applied median values to rank products as per their contribution into overall exposure (Table 3 ).

We detected that more than $70 \%$ of contribution made by food products contamination with lead, cadmium, mercury, and arsenic was determined by consumption of locally produced or grown food products.

It was especially interesting to examine products groups that made the greatest contribution into overall exposure. For more profound examination, grocery products were di- vided into the following categories: "bread", "bakery", "macaroni", "flour", "cereals", and "others". The lowest concentrations of lead $(0.004 \pm 0.0002 \mathrm{mg} / \mathrm{kg} ; \quad \mathrm{p} \leq 0.05), \quad$ arsenic $(0.004 \pm 0.0001 \mathrm{mg} / \mathrm{kg} ; \mathrm{p} \leq 0.05)$, cadmium $(0.004 \pm 0.0003 \mathrm{mg} / \mathrm{kg} ; \mathrm{p} \leq 0.05)$, and mercury $(0.001 \pm 0.0001 \mathrm{mg} / \mathrm{kg} ; \mathrm{p} \leq 0.05)$ were detected in "macaroni". The highest lead concentrations were detected in "flour" $(0.009 \pm 0.0006 \mathrm{mg} / \mathrm{kg}$; $\mathrm{p} \leq 0.05)$ and "cereals" $(0.008 \pm 0.0003 \mathrm{mg} / \mathrm{kg}$; $\mathrm{p} \leq 0.05)$. The highest arsenic concentrations were detected in "flour" $(0.008 \pm 0.0007$ $\mathrm{mg} / \mathrm{kg} ; \mathrm{p} \leq 0.05)$. The highest cadmium concentrations were also detected in "flour" 
$(0.009 \pm 0.0006 \mathrm{mg} / \mathrm{kg} ; \mathrm{p} \leq 0.05)$ and "cereals" $(0.009 \pm 0.0005 \mathrm{mg} / \mathrm{kg} ; \mathrm{p} \leq 0.05)$. The highest mercury concentration was detected in "bread" $(0.004 \pm 0.0003 \mathrm{mg} / \mathrm{kg} ; \mathrm{p} \leq 0.05)$. Overall, we can conclude that "flour" and "cereals" are the most contaminated among grocery products, and they are mostly produced locally and from local raw materials (Figure).

Examined meat products were divided into the following categories: "sausages", "meat", "poultry", and "minced meat products" (Figure 2). We detected that "meat" was the least contaminated among all these products (lead concentration $0.001 \pm 0.0005 \mathrm{mg} / \mathrm{kg}$; $\mathrm{p} \leq 0.05 ; \quad$ arsenic, $\quad 0.001 \pm 0.0009 \mathrm{mg} / \mathrm{kg}$; $\mathrm{p} \leq 0.05$; cadmium, $0.001 \pm 0.0005 \mathrm{mg} / \mathrm{kg}$; $\mathrm{p} \leq 0.05$; mercury, $0.0004 \pm 0.00001 \mathrm{mg} / \mathrm{kg}$; $\mathrm{p} \leq 0.05)$. The highest concentrations of lead $(0.008 \pm 0.0005 \mathrm{mg} / \mathrm{kg} ; \mathrm{p} \leq 0.05), \quad$ arsenic $(0.008 \pm 0.0003 \mathrm{mg} / \mathrm{kg} ; \mathrm{p} \leq 0.05)$, cadmium $(0,008 \pm 0.0009 \mathrm{mg} / \mathrm{kg} ; \mathrm{p} \leq 0.05)$, mercury $(0.004 \pm 0.0001 \mathrm{mg} / \mathrm{kg} ; \mathrm{p} \leq 0,05)$ were detected in "minced meat products" which were basically frozen semi-finished products (cutlets, pelmeni, meatballs, and others), and most of them were brought to Orenburg form other regions while most "neat" and "poultry" was produced locally.

To examine dairy products more profoundly, we divided them into 3 categories: "milk", sour milk products", and "other milk products" (buttermilk, etc.). We detected that "sour milk products" were the most contaminated with lead $(0.006 \pm 0.0002 \mathrm{mg} / \mathrm{kg})$, arsenic

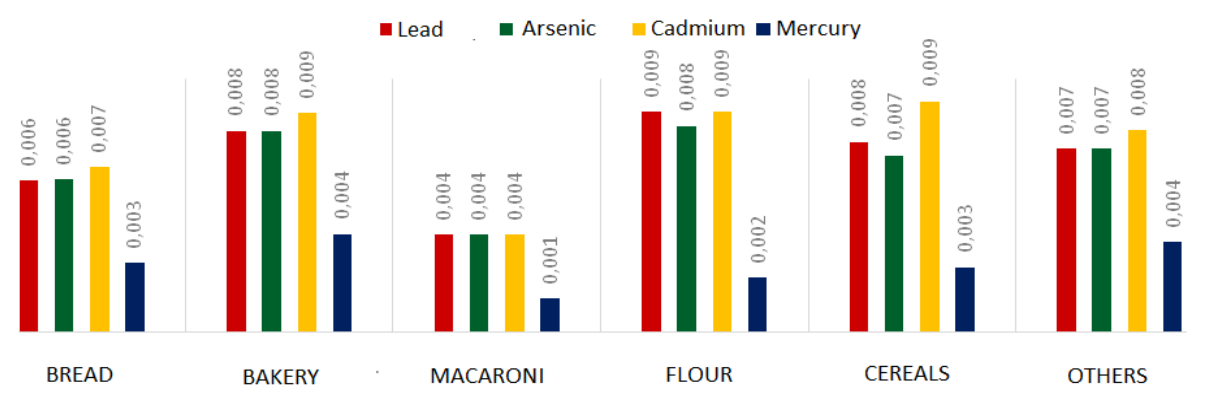

Figure 1 . Grocery products contamination with heavy metals, $\mathrm{mg} / \mathrm{kg}$

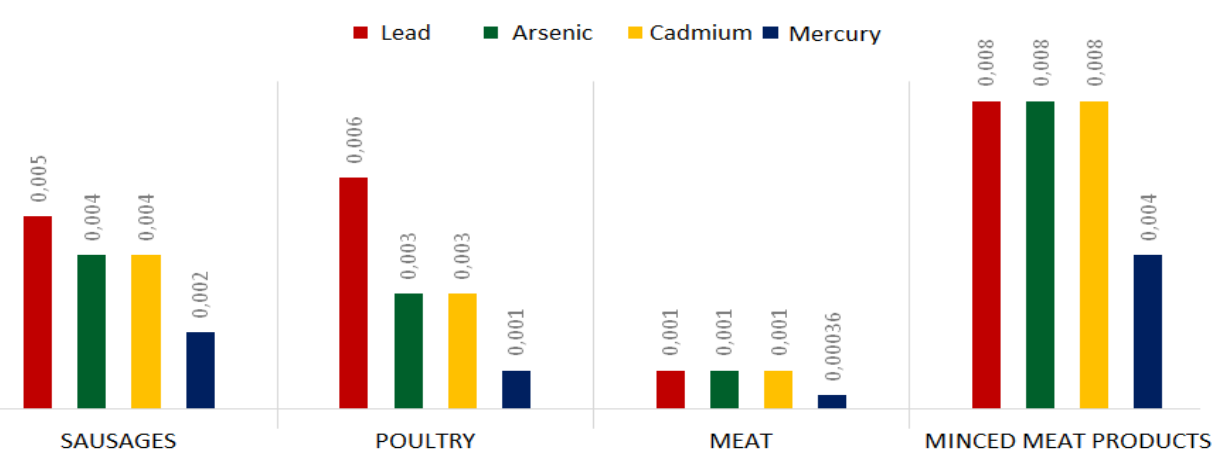

Figure 2. Meat products contamination with heavy metals, $\mathrm{mg} / \mathrm{kg}$

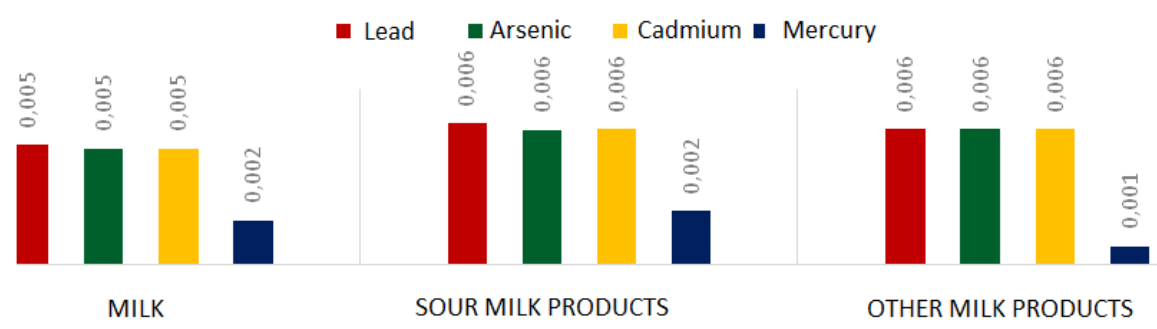

Figure 3. Dairy products contamination with heavy metals, $\mathrm{mg} / \mathrm{kg}$ 
$(0.006 \pm 0.0001 \mathrm{mg} / \mathrm{kg})$, and cadmium $(0.006 \pm$ $\pm 0.0006 \mathrm{mg} / \mathrm{kg}$ ) (Figure 3). As for "milk" concentration of lead in it amounted to $0.005 \pm 0.0009 \mathrm{mg} / \mathrm{kg}$; arsenic, $0.005 \pm 0.0008$ $\mathrm{mg} / \mathrm{kg}$; and cadmium, $0.005 \pm 0.0007 \mathrm{mg} / \mathrm{kg}$. Mercury contents in "milk" and "sour milk products" were practically the same $(0.002 \pm$ $\pm 0.0001 \mathrm{mg} / \mathrm{kg}$ ).

To determine non-carcinogenic hazard quotients, we applied values of conditionally tolerable weekly introduction (CTWI) of contaminants which were able to cumulate (MG 2.3.7.2519-096) with calculating weekly exposure. We detected that hazard quotients, both as per their median values and 90-th percentile ones, didn't exceed an acceptable level. Overall hazard index at a median and 90-th percentile level also didn't exceed permissible levels (Table 4).

Risk analysis as per organs and systems revealed that the highest risks were detected for the hormonal system, CNS, kidneys, and immune system; nevertheless, all those risks corresponded to hygienic requirements, both as per median values and 90 -th percentile ones (Table 5).

Carcinogenic risks were calculated as per three chemicals, namely, cadmium, arsenic, and lead; arsenic and cadmium are assigned into the first category of carcinogens according to the International Agency for Research on cancer (IARC). Carcinogenic risk assessment revealed that a risk caused by arsenic contents in food products could be estimated as unacceptable for population in general (individual lifelong risk was higher than $1 \times 10^{-4}$ ), both as per a median value and 90-th percentile one. Individual carcinogenic risks caused by exposure to lead and cadmium and calculated as per 90-the percentile were also unacceptable (Table 6).

We calculated population carcinogenic risk for the whole Orenburg region population (553,763 people); the calculation revealed that contamination with arsenic resulted in the maximum probability of oncologic diseases (441.9 new disease cases), and contamination with lead, the minimum one (9.4 new disease cases); contamination with cadmium resulted in 69.2 new cases. Overall, food products consumption could lead to additional 520.5 new oncologic diseases cases for 70 years under the worst possible scenario (90-th percentile).

We analyzed heavy metals introduction with drinking water and revealed that average concentrations of the examined chemicals in it didn't exceed permissible levels, lead concentration being equal to $0.14 \mathrm{MPC}$; arsenic, $0.2 \mathrm{MPC}$; cadmium, 0.48 MPC; and mercury, 0.04 MPC.

Daily absorbed doses amounted to 5.58E-05 for lead; 3.96E-05, arsenic; 1.38E-05, cadmium; and-6.14E-07, mercury. We calculated noncarcinogenic risks caused by the examined contaminants contents in drinking water and

Table 4

Hazard quotients related to non-carcinogenic effects occurrence

\begin{tabular}{|c|l|c|c|c|}
\hline \multicolumn{2}{|c|}{ Chemical } & $\begin{array}{c}\text { Exposure } \\
(\mathrm{mg} / \mathrm{kg} / \\
\text { week })\end{array}$ & $\begin{array}{c}\text { CTWI } \\
\mathrm{mg} / \mathrm{kg} \\
\text { b.w./ } \\
\text { week }\end{array}$ & $\begin{array}{c}\text { Hazard } \\
\text { quotient } \\
(\mathrm{HQ})\end{array}$ \\
\hline \multirow{2}{*}{ Lead } & med & 0.002 & \multirow{2}{*}{0.025} & 0.08 \\
\cline { 2 - 3 } \cline { 5 - 5 } & $90 \%$ & 0.003 & & 0.10 \\
\hline \multirow{2}{*}{ Arsenic } & med & 0.002 & \multirow{2}{*}{0.015} & 0.13 \\
\cline { 2 - 3 } \cline { 5 - 5 } & $90 \%$ & 0.003 & & 0.25 \\
\hline \multirow{2}{*}{ Cadmium } & med & 0.002 & \multirow{2}{*}{0.007} & 0.26 \\
\cline { 2 - 3 } \cline { 5 - 5 } & $90 \%$ & 0.002 & & 0.33 \\
\hline \multirow{2}{*}{ Mercury } & med & 0.001 & \multirow{2}{*}{0.005} & 0.12 \\
\cline { 2 - 3 } \cline { 5 - 5 } & $90 \%$ & 0.001 & & 0.27 \\
\hline \multirow{2}{*}{ Overall HI } & med & & & 0.59 \\
\cline { 2 - 3 } & $90 \%$ & & & 0.95 \\
\hline
\end{tabular}

Table 5

Overall hazard index for critical organs and systems in a body

\begin{tabular}{|l|c|c|}
\hline Organs and systems & $\begin{array}{c}\text { Hazard index, } \\
\text { HI med }\end{array}$ & $\begin{array}{c}\text { Hazard index, } \\
\text { HI 90 \% }\end{array}$ \\
\hline Central nervous system & 0.33 & 0.62 \\
\hline Nervous system & 0.21 & 0.35 \\
\hline Blood & 0.08 & 0.10 \\
\hline Hormonal system & 0.59 & 0.95 \\
\hline Reproductive system & 0.20 & 0.37 \\
\hline Skin & 0.21 & 0.35 \\
\hline Immune system & 0.25 & 0.52 \\
\hline Gastrointestinal tract & 0.13 & 0.25 \\
\hline Cardiovascular system & 0.13 & 0.25 \\
\hline Kidneys & 0.39 & 0.60 \\
\hline
\end{tabular}


Т аблица 6

Carcinogenic risks related to food exposure

\begin{tabular}{|c|c|c|c|c|c|c|c|}
\hline Chemical & CAS* & IARC** & EPA*** & $\mathrm{SF}_{\mathrm{O}} * * * *$ & $\mathrm{SF}_{\mathrm{I}} * * * * *$ & $\mathrm{ICR}^{2 * * * * * *} \mathrm{med}$ & ICR $90 \%$ \\
\hline 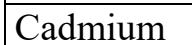 & $7440-43-9$ & 1 & B1 & 0 & 6.3 & 9.94E-05 & $1.25 \mathrm{E}-04$ \\
\hline Arsenic & $7440-38-2$ & 1 & A & 1.5 & 15 & $4.17 \mathrm{E}-04$ & $7.98 \mathrm{E}-04$ \\
\hline lead & $7439-92-1$ & $2 \mathrm{~A}$ & $\mathrm{~B} 2$ & 0 & 0.042 & $1.27 \mathrm{E}-05$ & $5.4 \mathrm{E}-04$ \\
\hline CRfo Sum & \multicolumn{5}{|c|}{-} & $5.29 \mathrm{E}-04$ & $1.5 \mathrm{E}-03$ \\
\hline
\end{tabular}

Notes:

${ }^{*}$ ChemicalAbstractsService.

${ }^{* *}$ International Agency for Research on Cancer.

${ }^{* * *}$ United States Environmental Protection Agency; EPA.

${ }^{* * * *}$ Slope Factor for oral $\mathrm{SF}_{\mathrm{O}}$ introduction of a toxicant in a body.

${ }^{* * * * * *}$ Slope Factor for inhalation $\mathrm{SF}_{\mathrm{I}}$ introduction of a toxicant in a body.

${ }^{* * * * * *}$ Individual carcinogenic risk.

detected the highest hazard quotient for arsenic (HQ-0.13). Hazard quotients (HQ) calculated for cadmium, mercury, and lead, were lower than 0.01 .

Carcinogenic risk assessment revealed that individual carcinogenic risk caused by arsenic contents in drinking water amounted to 5.94E-05; lead contents, 2.62E-06; cadmium contents, 5.25E-06. Probable additional oncologic cases caused by oral introduction of a chemical with drinking water amounted to 32.8 for arsenic; 1.5 , for lead; 2.9, for cadmium, for 70 years.

We assessed combined effects produced by heavy metals in food products and drinking water under oral introduction on the basis of hazard index 9HI); the assessment showed that HI for food products amounted to 0.44 (90-the percentile was applied); and to 0.18 for drinking water. Therefore, total hazard index (THI) amounted to 0.62 .

We assessed total carcinogenic risk caused by combined oral introduction and revealed that $\mathrm{CR}$ for food products amounted to 9.4E-04 (90-th percentile was applied); and to 1.47E-03 for drinking water. Therefore, total carcinogenic risk (TCR) amounted to 1.5E-03.

Basic uncertainties in this work are caused by incomplete data on parameters required to assess exposure as such an assessment depends on more detailed study of a market basket which allows to quantitatively estimate food products consumption by various population groups. The most authentic as- sessment of influence exerted on health by combined oral introduction of heavy metals can be performed only via targeted and wellplanned research with lower variability and uncertainty, based on data specifically obtained for the sake of such research and scenarios which are the most approximate to real life conditions.

Conclusion. We detected that annual food products consumption as per the examined food products groups was by $93 \mathrm{~kg}$ higher per capita in Orenburg region than in the country in general.

Calculated median and 90-th percentile values for concentrations of heavy metals (cadmium. lead, mercury, and arsenic) corresponded to the requirements fixed by CU TR $021 / 2011$ "On food products safety" ${ }^{4}$ in all the examined food products groups. Average annual concentrations of heavy metals in drinking water didn't exceed hygienic standards.

Milk and dairy products had the first rank place as per their contribution into overall exposure to lead, cadmium, and arsenic; these products were mainly produced in the region. The first rank place as per a contribution into overall exposure to mercury belonged to vegetables and melons. More than $70 \%$ of the contribution made into food products contamination with lead, cadmium, mercury, and arsenic are determined by consumption of products which were grown or produced mainly in the region.

Hazard coefficients related to non-carcinogenic effects as well as hazard indexes for 
critical organs and systems caused by heavy metals contents both in drinking water and food products didn't exceed acceptable levels.

As we assessed total carcinogenic risk caused by combined oral introduction of heavy metals, we revealed an unacceptable risk level (total carcinogenic risk (TCR) which amounted to $1.5 \mathrm{E}-03$, as per 90 -th per- centile). Probability of additional oncologic diseases could reach 557 cases under the worst possible scenario.

Funding. The research was not granted any sponsor support.

Conflict of interests. The authors state there is no any conflict of interests.

\section{References}

1. Shur P.Z., Zaitseva N.V., Khotimchenko S.A., Fedorenko E.V., Sychik S.I., Fokin V.A., Suvorov D.V., Zelenkin S.E. On the issue of establishing acceptable daily intake of chemical substancesin food products according to health risk criteria. Gigiena i sanitariya, 2019, vol. 98, no. 2, pp. 189-195. DOI: 10.18821/0016-9900-2019-98-2-189-195 (in Russian).

2. Popova A.Yu. Strategic priorities of the Russian Federation in the field of ecology from the position of preservation of health of the nation. Zdorov'e naseleniya i sreda obitaniya, 2014, vol. 251, no. 2, pp. 4-7 (in Russian).

3. May I.V., Nikiforova N.V. Methodological approaches to optimization of the laboratory control over product safety within risk-based surveillance framework // Gigiena i sanitariya, 2019, vol. 98, no. 2, pp. 205-213. DOI: 10.18821/0016-9900-2019-98-2-205-213 (in Russian).

4. Rakitskii V.N., Avaliani S.L., Shashiia T.A., Dodina N.S. Actual problems of population health risks management in Russia. Gigiena i sanitariya, 2018, vol. 97, no. 6, pp. 572-575 (in Russian).

5. Rakhmanin Yu.A., Mikhailova R.I. Food risks analysis and water safety. Health Risk Analysis, 2018, no. 4, pp. 31-42. DOI: 10.21668/health.risk/2018.4.04.eng

6. Fomina S.F., Stepanova N.V. Izuchenie pitaniya detei g. Kazani i risk zabolevaemosti, svyazannyi s khimicheskoi kontaminatsiei pishchevykh produktov [The study of the nutrition of children in Kazan and the risk of morbidity associated with chemical contamination of food]. Voprosy pitaniya, 2018, vol. 87, no.S5, pp. 197-198 (in Russian).

7. Fridman K.B., Novikova Yu.A., Belkin A.S. On the issue of the use of health risk assessment techniques for hygienic characteristics of water supply systems. Gigiena $i$ sanitariya, 2017, vol. 96, no. 7, pp. 686-689 (in Russian).

8. Ivashkevich L.S., Kovshova T.V., Vashkova O.N., Velentei Yu.N. Working out procedures for analyzing toxic elements content in oil products and oil raw materials using atomic-emission spectrometry with inductive-bound plasma to assess products safety. Health Risk Analysis, 2017, no. 2, pp. 128-135. DOI: $10.21668 /$ health.risk/2017.2.14.eng

9. Zaitseva N.V., Trusov P.V., Kir'yanov D.A. Mathematic concept model of accumulation of functional disorders associated with environmental factors. Meditsina truda i promyshlennaya ekologiya, 2012, no. 12, pp. 40-45.

10. Milošković A., Milošević Đ., Radojković N., Radenković M., Đuretanović S., Veličković T., Simić V. Potentially toxic elements in freshwater (Alburnus spp.) and marine (Sardina pilchardus) sardines from the Western Balkan Peninsula: An assessment of human health risk and management. Science of the Total Environment, 2018, vol. 644, no. 10, pp. 899-906. DOI: 10.1016/j.scitotenv.2018.07.041

11. Vejarano R., Siche R. Evaluation of biological contaminants in foods by hyperspectral imaging: A review. International Journal of Food Properties, 2017, vol. 20, pp. 1264-1297. DOI: 10.1080/10942912.2017.1338729

12. Kiku P.F., Kislitsyna L.V., Bogdanova V.D., Sabirova K.M. Hygienic evaluation of the quality of drinking water and risks for the health of the population of the primorye territory. Gigiena $i$ sanitariya, 2019, vol. 98, no. 1, pp. 94-101 (in Russian).

13. Boev V.M., Lestsova N.A., Amerzyanova N.M., Makarova T.M., Sizova G.V., Setko A.G., Utenin V.V. Hygienic assessment of the levels of trace elements in drinking water and foodstuffs in the sociohygienic monitoring system. Gigiena i sanitariya, 2002, no. 5, pp. 71-73 (in Russian). 
14. Zholdakova Z.I., Kharchevnikova N.V., Mamonov R.A., Sinitsyna O.O. Methods for estimating the combined effect of substances. Gigiena i sanitariya, 2012, no. 2, pp. 86-90 (in Russian).

15. Liu Y., Liu G., Yuan Z., Liu H., Lam P.K.S. Presence of arsenic, mercury and vanadium in aquatic organisms of Laizhou Bay and their potential health risk. Marine Pollution Bulletin, 2017, vol. 125 , no. $1-2$, pp. $176-185$.

16. Kislitsyna L.V., Ivanova I.L., Kiku P.F. Estimation of risk of the likely impact of heavy metals in food on health of population of the Primorsky region. Zdorov'e. Meditsinskaya ekologiya. Nauka, 2015, no. 4 (62), pp. 78-83 (in Russian).

17. FrolovaO.A., Tafeeva E.A., Frolov D.N., Bocharov E.P. Alimentary-dependent diseases of the population and the hygienic characteristic of the factors of the risk of their development in the territory of the republic of Tatarstan. Gigiena i sanitariya, 2018, vol. 97, no. 5, pp. 470-473 (in Russian).

18. Lyzhina A.V., Unguryanu T.N., Rodimanov A.V. Health risk assessment associated with contamination by heavy metals of food products. Zdorov'e naseleniya i sreda obitaniya, 2018, no. 7 (304), pp. 4-7 (in Russian).

19. Boev V.M., Zelenina L.V., Kryazhev D.A., Tulina L.M., Neplokhov A.A. Analysis on exposure carcinogenic risk of environmental factors on health largest industrial cities and malignant tumors. Zdorov'e naseleniya i sreda obitaniya, 2016, no. 6, pp. 3-6 (inRussian).

Boev V.M., Kryazheva E.A., Begun D.N., Borshchuk E.L., Kryazhev D.A. Hygienic assessment of population health risks caused by combined oral introduction of heavy metals. Health Risk Analysis, 2019, no. 2, pp. 35-43. DOI: 10.21668/health.risk/2019.2.04.eng

Received: 13.03 .2019

Accepted: 20.05.2019

Published: 30.06.2019 